\title{
The Effects CNG Injection Timing on Engine Performance and Emissions of A Diesel Dual Fuel Engine
}

\author{
Moch. Aziz Kurniawan, Dori Yuvenda, and Bambang Sudarmanta
}

\begin{abstract}
Sequential combustion process on diesel dual fuel engine with compressed natural gas (CNG) fuel was complex. The problems of diesel dual fuel with CNG gas are reduced thermal efficiency and resulting in high carbon monoxide (CO) and unburned hydrocarbon (HC) emissions. The right setting between combustion air, diesel pilot fuel, and CNG gas fuel can improvement the performance and emissions. The experiment was conducted with diesel fuel conventional and dual fuel mode with CNG fuel in a single cylinder, four strokes, constant speed $(1500 \mathrm{rpm})$ diesel engine type diamond DI 800. Performance parameters such as thermal efficiency and specific fuel consumption (SFC), emissions such as CO, HC, and smoke density are determined at five starts of injection timing (SOI) $\mathrm{CNG}$ of $7^{\circ} \mathrm{CA}, 9^{\circ} \mathrm{CA}, 110^{\circ} \mathrm{CA}, 130^{\circ} \mathrm{CA}$, dan $150^{\circ} \mathrm{CA}$ ATDC with ECU programmable of Vemstune software. The results indicated that retarded CNG injection timings improved engine performance and emissions diesel dual fuel. Start of CNG injection timing optimization at $130^{\circ} \mathrm{CA}$ ATDC with increased thermal efficiency $14,35 \%$ and decreased specific fuel consumption (SFC) $8,83 \%$. in addition, it decreased CO emissions 21,35\%, HC emissions 17,93\%, and PM emissions lower 34,98\%. However, engine performance diesel dual fuel lower than a conventional diesel engine.
\end{abstract}

Keywords—Diesel Dual Fuel, the Start of CNG Injection Timing, Engine Performance, Emissions.

\section{INTRODUCTION}

$\mathrm{D}$ iesel Dual Fuel (DDF) is the standard diesel engine with Compressed Natural Gas (CNG) and diesel fuel. $\mathrm{CNG}$ is one type of alternative gas fuel to reduce fossil fuel oil. CNG fuel potential to be applied to internal combustion engines with dual fuel technology [1]. The combustion process on diesel dual fuel mode occurs in sequential form. First, diesel fuel pilot combustion. Second CNG fuel combustion [2]. Dual fuel diesel engine technology developed is a gas fuel input system. The first is a mixer feed technology that works by mixing air-fuel gas using a mixer before entering the suction conduit [3][4]. Next is a low pressure model input technology that works by doing gas injection on suction channels with low pressure [5][6]. CNG gas pressure was varied to improve engine performance of diesel dual fuel mode. It can improve thermal efficiency. But it lowers thermal efficiency than conventional diesel [5]. Start of Injection CNG $35^{\circ}, 40^{\circ}$, and $45^{\circ}$ was varied with duration setting. It can improve the best of thermal efficiency in $45^{\circ} \mathrm{CA}$ ATDC. But it lower than conventional diesel [7]. CNG gas pressure and the start of injection $5^{\circ}, 30^{\circ}, 55$, and $80^{\circ} \mathrm{CA}$ ATDC. It found the optimal resulted at $80^{\circ}$ and 1.5 injecting gas pressure can improve thermal efficiency, but it lower than conventional diesel [8]. Start of injections Gas CNG was varied in $-500^{\circ},-460^{\circ},-300^{\circ},-260^{\circ}$ CA ATDC. Retarded injection timing of $\mathrm{CNG}$ at $-260^{\circ} \mathrm{CA}$ ATDC can improve thermal efficiency and exhaust emissions on diesel dual fuel engine mode. It suggests that retarded CNG injection timing formed stratified like air fuel mixture in cylinder chamber [9]. Combination of the start of injection gas $\mathrm{CNG}-480^{\circ},-420^{\circ},-300^{\circ},-260^{\circ} \mathrm{CA}$ ATDC with an injection pressure of pilot diesel was varied. It found that retarded injection timing of $\mathrm{CNG}$ at $-260^{\circ}$ CA ATDC and used the higher injection pressure

Moch. Aziz Kurniawan, Dori Yuvenda, and Bambang Sudarmanta are with Department of Mechanical Engineering, Institut Teknologi Sepuluh Nopember, Surabaya, 60111, Indonesia, E-mail: sudarmanta@me.its.ac.id. can improve thermal efficiency and exhaust emissions [10]. The objective of this study is to experimentally investigate the behaviors of engine performance and emissions under the various start of $\mathrm{CNG}$ injection timing in a diesel dual fuel engine.

\section{METHOD}

Experiment was conducted with diesel fuel conventional and dual fuel mode with $\mathrm{CNG}$ fuel in a single cylinder, 4 strokes, constant speed (1500 rpm), water cooled, direct injection, $7 \mathrm{hp}(5.2 \mathrm{~kW})$, bore $82 \mathrm{~mm}$ and stroke $78 \mathrm{~mm}$, compression ratio 18:1 diesel engine type diamond DI 800 . The complete engine specification in Table 1.

The fuel modified into dual fuel system with indirect injection CNG gas through the intake manifold. The experimental setup is shown in fig.1. An electrical dynamometer was used for load measurement. Test were conducted at different loads $(25 \%, 50 \%, 75 \%, 100 \%)$. The mass flow rate of air and CNG gas measured by static pitot tube and digital manometer. The mass flow rate of diesel fuel measured by burret meter. $\mathrm{CO}, \mathrm{HC}$, and PM emissions measured by Stargas 989 gas analyzer and smokemeter. Start of $\mathrm{CNG}$ injection timing was varied in $70^{\circ} \mathrm{CA}, 90^{\circ} \mathrm{CA}, 110^{\circ} \mathrm{CA}, 130^{\circ} \mathrm{CA}$, dan $150^{\circ} \mathrm{CA}$ ATDC. The illustration varied of $\mathrm{CNG}$ injection timings is shown in fig.2. The duration of $\mathrm{CNG}$ injection is constant at $70^{\circ} \mathrm{CA}$. The setting of $\mathrm{CNG}$ injection and duration used ECU programmable of VEMSTUNE software. The pilot injection parameters (pilot injection timing and pressure) and natural gas injection pressure remain constant is 2 bar [11].

\section{RESULTS AND DISCUSSION}

A. The effect starts of CNG Injection Timing on the Thermal Efficiency

Thermal efficiency influenced by the amount of heat energy utilization stored in the fuel to be converted to effective power. Thermal efficiency increased with 


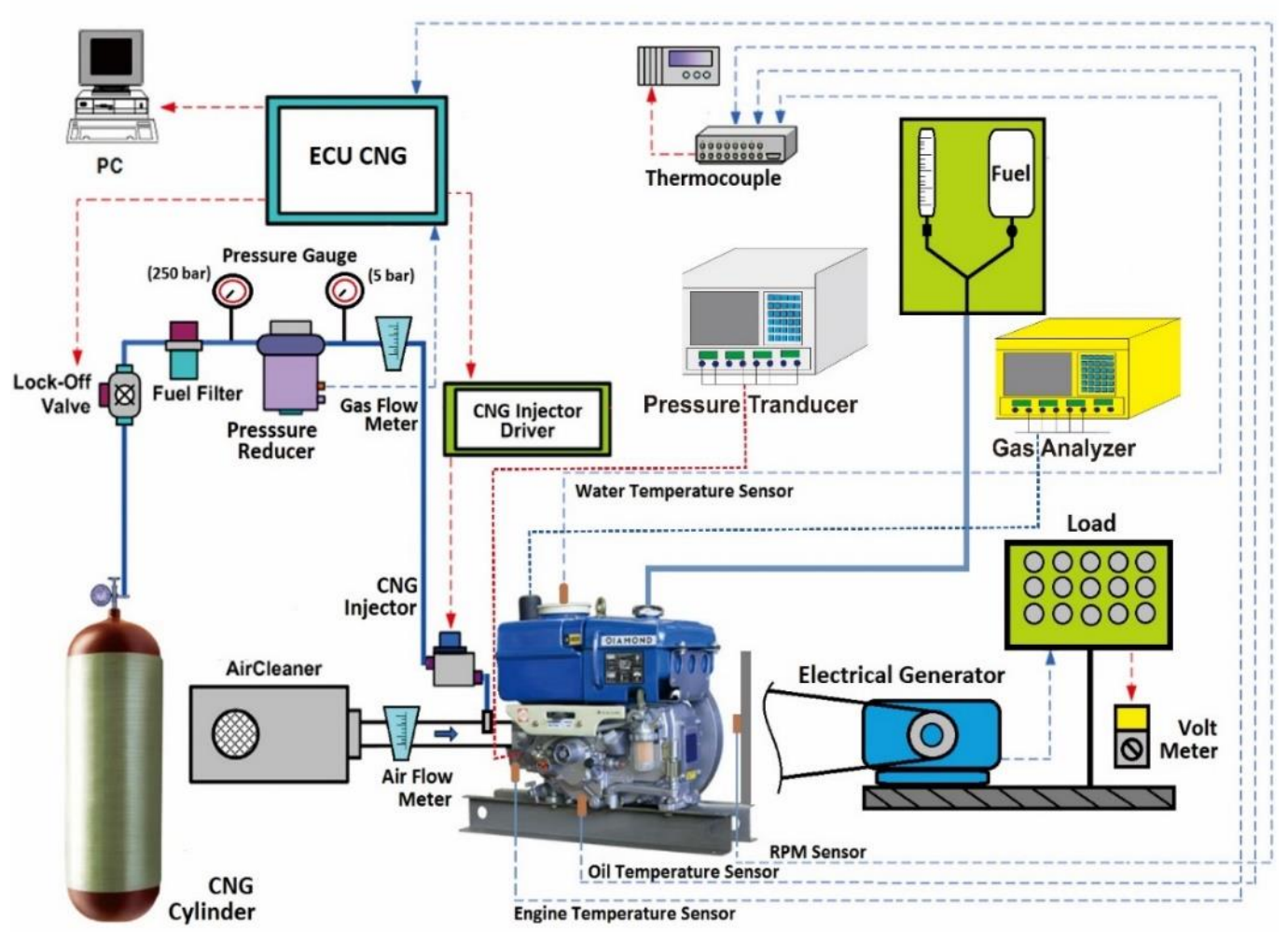

Figure 1. Experimental Setup.

TABLE 1.

ENGINE CHARACTERISTIC

\begin{tabular}{lc}
\multicolumn{1}{c}{ Items } & SNGINE CHARACTERISTIC \\
\hline \hline Type & DI 800 \\
Model & One cylinder, four stroke \\
Bore x Stroke & $82 \times 78 \mathrm{~mm}$ \\
Max. Power & $8 \mathrm{HP}(6 \mathrm{KW}) / 2400$ \\
Continous Power & $7 \mathrm{HP}(5.22 \mathrm{KW}) / 2200 \mathrm{rpm}$ \\
Compression Ratio & $18: 1$ \\
Injection pilot diesel & $13^{0} \mathrm{BTDC}$ \\
Cooling system & water cooling \\
Lube capacity & 1,8 liters \\
\hline \hline
\end{tabular}

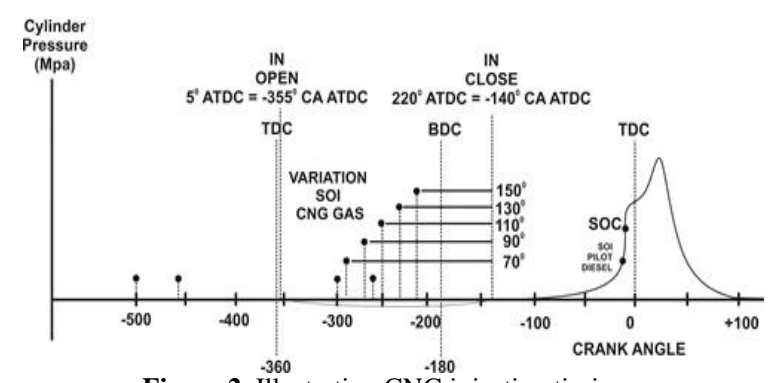

Figure 2. Illustration $\mathrm{CNG}^{-180}$ injection timings.

addition load as shown in Figure 3. The maximum increased value at $75 \%$ load compared with minimum one. Addition load increased thermal efficiency because more fuel that can be converted during the combustion process into the power discharged through the engine shaft. However, thermal efficiency decreased in full load because it can't be converted to engine power during the combustion process in the combustion chamber, so much of the fuel is wasted with combustion gas. Thermal efficiency is increased with the retarded CNG injection timing as shown in Figure 3. The maximum increased value is $14,35 \%$ compared with the minimum one at the start of injection (SOI) $\mathrm{CNG} 130^{\circ} \mathrm{CA}$. However, it lowers $43,02 \%$ than conventional diesel fuel engine. The results indicated that the retarded start of $\mathrm{CNG}$ injection

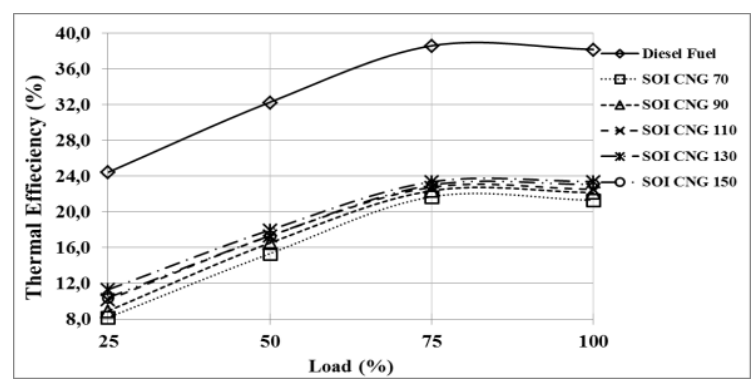

Figure 3. Graph of thermal efficiency versus \% load.

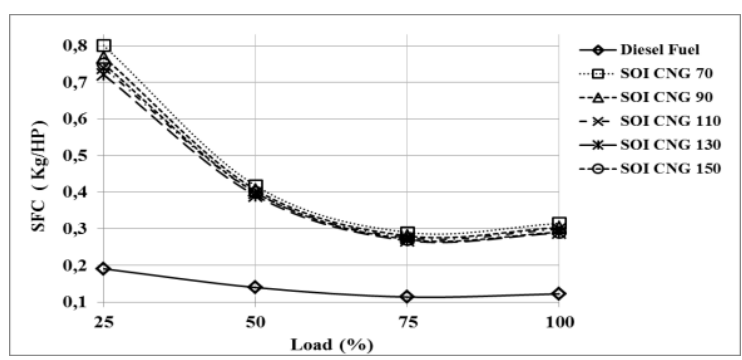

Figure 4. Graph of SFC versus load.

timing increased the amount of air in the combustion chamber. So, more burning fuel with oxygen and it can make better performance.

B. The Effect Starts of CNG Injection Timing on the Specific Fuel Consumption (SFC)

The specific fuel consumption (SFC) is influenced by the amount of fuel needed to produce one unit of power in an hour. If the value of SFC decreased, the fuel consumed more effective. SFC decreased with addition load as shown in Figure 4. Addition load the engine becomes more effective at consuming fuel. The maximum decreased value at $75 \%$ load compared with minimum one. SFC value will be increased at full load. Thermal efficiency is increased with the retarded $\mathrm{CNG}$ 


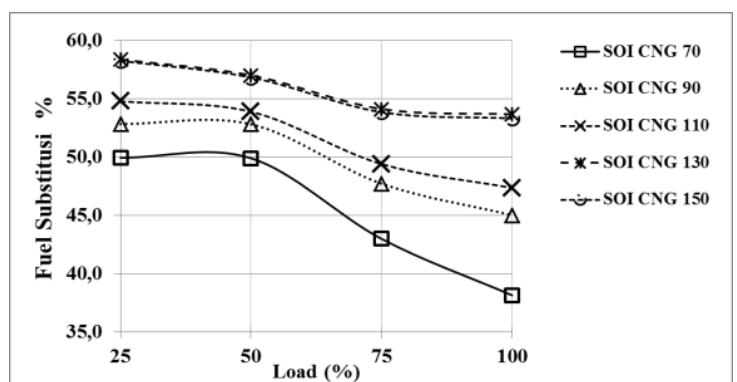

Figure 5. Graph of Substitusi fuel versus load.

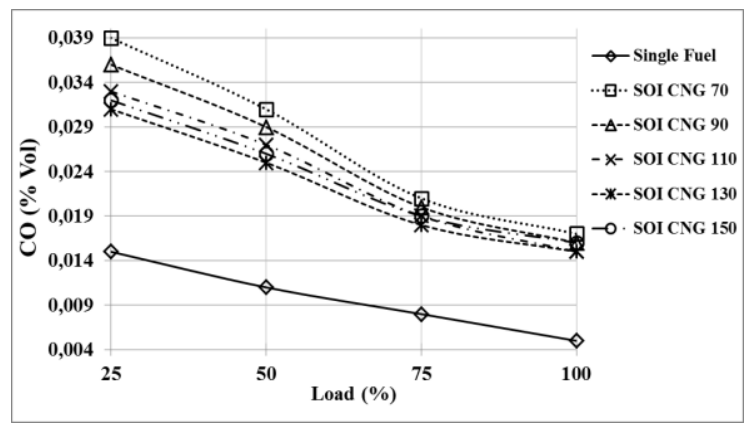

Figure 6. Graph of $\mathrm{CO}$ emission versus load.

injection timing as shown in Fig. Figure 4. The maximum increased value is $8,83 \%$ compared with the minimum one at the start of injection (SOI) CNG $130^{\circ} \mathrm{CA}$. However, it lowers $63,09 \%$ than Conventional diesel fuel engine. The results indicated that the retarded start of CNG injection timing increased the amount of air in the combustion chamber. So, more burning fuel with oxygen and it can make fuel consumption more effective.

\section{The Effect Starts of CNG Injection Timing on Diesel Fuel Substitution}

Diesel fuel substitution is replaced diesel fuel by CNG at every load. The use of CNG fuel makes the flow rate of diesel fuel reduced and replaced by CNG fuel. Diesel fuel substitution decreased by addition load as shown in Figure 5. Addition load makes the amount of diesel oil needed to keep the constant rotation, so the percentage of diesel fuel substitution is getting smaller. The maximum fuel substitution is $55,81 \%$ compared with the conventional diesel fuel engine at the start of injection (SOI) $\mathrm{CNG} 130^{\circ} \mathrm{CA}$ ATDC. The results indicated that the retarded start of $\mathrm{CNG}$ injection timing increased the amount of air in the combustion chamber. So, energy from diesel fuel replaced by CNG fuel and more burning fuel with oxygen.

\section{The Effect Starts of CNG Injection Timing on Carbon Monoxide (CO) Emissions}

Carbon Monoxide (CO) emissions are produced by burning a little oxygen. This occurred because, on a dual fuel system, the fuel mixture is too rich so that the small oxygen into the combustion chamber. $\mathrm{CO}$ emissions is another harmful emission from the engine, and its formation is a function of in-complete burned fuel availability and in-cylinder combustion temperature, both of which control the rate of fuel decomposition and oxidation. $\mathrm{CO}$ emissions decreased with addition load as shown in Figure 6 Addition load the engine becomes improvement combustion process because the diesel fuel addition with addition loads, so the high temperature of combustion chamber and $\mathrm{CO}$ emissions decreasing. $\mathrm{CO}$

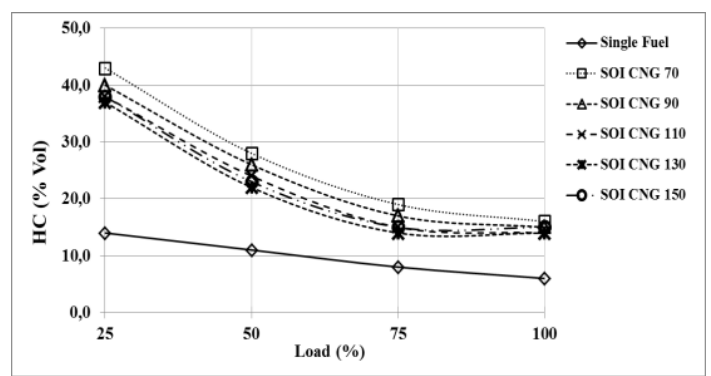

(a)

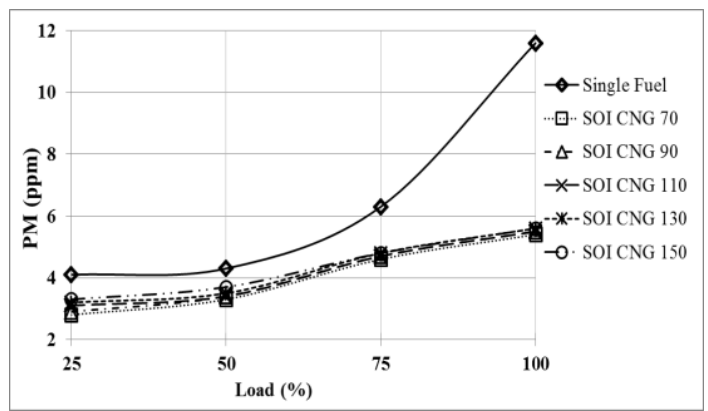

(b)

Figure 7. (a) Graph of HC emission versus load, (b) Graph of PM emission versus load

emissions decreased with the retarded start of CNG injection timing as shown in Fig. 6. The maximum decreased value is $21,35 \%$ compared with the minimum one at the start of injection (SOI) $\mathrm{CNG} 130^{\circ} \mathrm{CA}$. However, it higher $56,18 \%$ than conventional diesel fuel engine.

\section{E. The effect starts of $C N G$ injection timing on hydrocarbon $(\mathrm{HC})$ emission}

Hydrocarbon (HC) emissions are the consequence of incomplete combustion of hydrocarbon fuel. While the temperature for complete oxidation of $\mathrm{HC}$ is lower, $\mathrm{Hc}$ emissions decreased with addition load as shown in Figure 7. Addition load the engine becomes improvement combustion process because the diesel fuel addition with addition loads, so the high temperature of the combustion chamber and $\mathrm{HC}$ emissions decreasing. $\mathrm{HC}$ emissions decreased with the retarded start of CNG injection timing as shown in Figure 7. The maximum decreased value is $17,93 \%$ at the start of injection (SOI) $\mathrm{CNG} 130^{\circ} \mathrm{CA}$ compared with the minimum one. However, it higher 55,17\% than conventional diesel fuel engine.

F. The effect starts of CNG injection timing on the particulate matters (PM) emission

Particulate Matters (PM) emissions produced by burned solar fuels. It replaced by CNG fuel so that diesel fuel flows less than single fuel. Little of diesel fuel produced smaller PM emissions, so dual fuel mode with CNG fuel decreased PM emissions. Retarded the CNG injection time can allow the oxygen to enter the larger combustion chamber so that more diesel and CNG fuels are burned when oxygen into the combustion chamber feels sufficient. PM emissions increased with addition load as shown in Figure 8.

Addition load the engine becomes addition diesel fuel, so PM emissions are increasing. PM emissions increased $6,01 \%$ with the retarded start of $\mathrm{CNG}$ injection timing $130^{\circ} \mathrm{CA}$ ATDC compared with the minimum one as shown in Fig. 7b. The maximum decreased value is 
$34,98 \%$ at the start of injection (SOI) $\mathrm{CNG} 70^{\circ} \mathrm{CA}$ compared with conventional diesel fuel engine.

\section{SUMMARY}

The combustion process on diesel dual fuel mode occurs in sequential form - first, diesel fuel pilot combustion. And then $\mathrm{CNG}$ fuel combustion. The right setting between combustion air, diesel pilot fuel, and $\mathrm{CNG}$ fuel can improvement the performance and emissions. In the present work, an experimental investigation has been conducted to explore the effect start of CNG injection timing on engine performance and emissions. By the results and discussions presented above, the conclusions can be summarized as the following:

1. Diesel dual fuel engines in general decreased engine performance. Retarded start of CNG injection timing improved engine performance. Optimal retarded start of $\mathrm{CNG}$ injection timing at $130^{\circ} \mathrm{CA}$ ATDC increased thermal efficiency $14,35 \%$ compared with dual fuel minimum one. Also, it decreased specific fuel consumption (SFC) 8,83\% compared with dual fuel minimum one. The results indicated that the retarded start of CNG injection timing increased the amount of air in the combustion chamber. So, more burning fuel with oxygen and it can make better performance.

2. Diesel dual fuel engines in general increased $\mathrm{CO}$ emissions average $56.18 \%$ and HC emissions $55.17 \%$ compared with diesel fuel conventional. Retarded start of CNG injection timing improved emissions in dual fuel mode. Optimal retarded start of CNG injection timing at $130^{\circ} \mathrm{CA}$ ATDC decreased $\mathrm{CO}$ emissions $21,35 \%$ and HC emissions $17,93 \%$. PM emissions lower $34,98 \%$ than conventional diesel fuel engine.

\section{AKNOWLEDGEMENTS}

This article is one of the requirements to complete a postgraduate program at Institut Teknologi Sepuluh Nopember Surabaya. Do not forget to thank the DDF team of Mechanical engineering ITS.

\section{REFERENCES}

[1] M. Y. E. Selim, "Pressure-time characteristics in diesel engine fueled with natural gas," Renew. energy, vol. 22, no. 4, pp. 473-489, 2001.

[2] F. Königsson, Advancing the Limits of Dual Fuel Combustion, vol. 14, no. 2012. 2012

[3] M. Y. E. Selim, "Sensitivity of dual fuel engine combustion and knocking limits to gaseous fuel composition," Energy Convers. Manag., vol. 45, no. 3, pp. 411-425, 2004.

[4] K. Wannatong, N. Akarapanyavit, and S. Siengsanorh "Combustion and Knock Characteristics of Natural Gas Diesel Dual Fuel Engine Combustion and Knock Characteristics of Natural Gas Diesel Dual Fuel Engine," no. October, 2017.

[5] C. Paper, D. Yuvenda, S. Resmi, and U. Negeri, "Karakterisasi Performa Mesin Sistem Dual Fuel Menggunakan Pressure Reducer Adaptive ...," no. April 2016, 2015.

[6] B. Sudarmanta, "The Performance Of Fossil Diesel-Syn Gas Dual Fuel Compression Ignition Engine For 3 KW."

[7] A. Arif et al., "Karakterisasi Performa Mesin Diesel Dual Fuel Solar-Cng Tipe Lpig Dengan Pengaturan,” 2015, no. 2013, pp. $1-8$.

[8] D. Yoko and B. Sudarmanta, "Studi Eksperimen Unjuk Kerja Mesin Diesel Menggunakan Sistem Dual Fuel Solar - Gas CNG dengan Variasi Tekanan Injeksi Gas dan Derajat Waktu Injeksi," 2016, vol. 5, no. 2, pp. 604-609.

[9] B. Yang, X. Wei, C. Xi, Y. Liu, K. Zeng, and M. C. Lai, "Experimental study of the effects of natural gas injection timing on the combustion performance and emissions of a turbocharged common rail dual-fuel engine," Energy Convers. Manag., vol. 87, pp. 297-304, 2014.

[10] B. Yang, C. Xi, X. Wei, K. Zeng, and M. C. Lai, "Parametric investigation of natural gas port injection and diesel pilot injection on the combustion and emissions of a turbocharged common rail dual-fuel engine at low load," Appl. Energy, vol. 143, pp. 130-137, 2015.

[11] D. Yuvenda, B. Sudarmanta, and E. Alwi, "Analisis Kekuatan Pegas Pressure Reducer Sebagai Penurunan Tekanan Pada Mesin Duel Fuel," vol. 17, no. 2, 2017. 